\title{
Faktor-Faktor yang Berhubungan dengan Kadar Hemoglobin pada Ibu Hamil di Puskesmas Lolak
}

\author{
${ }^{1}$ I Putu A. Wiraprasidi \\ ${ }^{2}$ Shirley E. Kawengian \\ ${ }^{2}$ Nelly Mayulu
}

\author{
${ }^{1}$ Program Studi Pendidikan Dokter Fakultas Kedokteran Universitas Sam Ratulangi Manado \\ ${ }^{2}$ Bagian Ilmu Gizi Fakultas Kedokteran Universitas Sam Ratulangi Manado \\ Email: putuwiraprasidi@gmail.com
}

\begin{abstract}
The first 1000 days of early life nutrition is the golden period of growth and development that does not occur in other age groups. During pregnancy, energy needs and nutrient intake have to be improved. Inadequate nutrition and some factors that influence hemoglobin level in this period may increase the risk for both mother and fetus. This study was aimed to determine the factors associated with hemoglobin levels among pregnant women at Lolak Primary Health Center. This was an analytical study with a cross-sectional design. Samples were obtained by using total sampling method and the target population was pregnant women in the area of Lolak Primary Health Center. The results showed that each variable had no significant relationship with hemoglobin level of pregnant women $(P>0.05)$. Conclusion: There was no statistically significant relationship between hemoglobin level and the age of pregnant women, gestational age, inter-pregnancy interval, mid upper arm circumference (MUAC), occupational status, educational level, family income as well as consumption pattern.
\end{abstract}

Keywords: pregnant women, hemoglobin level, consumption pattern

\begin{abstract}
Abstrak: Periode 1000 hari pertama nutrisi awal kehidupan merupakan periode emas terjadinya proses tumbuh kembang yang sangat cepat yang tidak terjadi pada kelompok usia lain. Pada masa kehamilan, kebutuhan energi dan asupan gizi pada diet perlu ditingkatkan. Tidak adekuatnya nutrisi serta beberapa faktor yang memengaruhi kadar hemoglobin pada periode ini dapat meningkatkan resiko terjadinya gangguan pada ibu hamil maupun janin. Penelitian ini bertujuan untuk mengetahui faktor-faktor yang berhubungan dengan kadar hemoglobin ibu hamil di Puskesmas Lolak. Jenis penelitian ialah analitik dengan desain potong lintang. Pengambilan sampel menggunakan metode total sampling dengan populasi target ibu hamil di wilayah Puskesmas Lolak. Dari hasil penelitian diperoleh nilai $P>0,05$ untuk masing-masing variabel. Simpulan: Tidak terdapat hubungan bermakna antara kadar hemoglobin dengan usia ibu, usia kehamilan, jarak kehamilan, ukuran LILA, status pekerjaan, tingkat pendidikan, pendapatan keluarga, dan pola konsumsi.
\end{abstract}

Kata kunci: ibu hamil, kadar hemoglobin, pola konsumsi

Periode 1000 hari pertama sering juga disebut window of opportunities merupakan periode emas (golden period) terjadinya proses tumbuh kembang yang sangat cepat yang tidak terjadi pada kelompok usia lain. Periode ini merupakan waktu yang kritis, dan jika tidak dimanfaatkan dengan baik akan terjadi kerusakan yang bersifat permanen. ${ }^{1-2}$

Seribu hari pertama kehidupan di tataran global disebut scaling up nutrition (SUN) yang merupakan upaya global dari berbagai negara dalam rangka memperkuat komitmen dan aksi percepatan perbaikan 
gizi, khususnya penanganan gizi dari masa kehamilan hingga anak usia 2 tahun. Upaya ini merupakan respon negara-negara di dunia terhadap kondisi status gizi di sebagian besar negara berkembang dan akibat kemajuan yang tidak merata dalam mencapai tujuan millenium development goals (MDGs). ${ }^{2}$

Scaling up nutrition memfokuskan pada 1000 hari pertama kehidupan. Gerakan 1000 hari pertama terdiri dari intervensi gizi spesifik dan intervensi gizi sensitif. Intervensi gizi sensitif umumnya dilakukan di luar sektor kesehatan dan bersifat jangka panjang dan sasaran lebih ke masyarakat umum. Intervensi gizi spesifik bertujuan langsung pada perkembangan dan nutrisi janin dan anak. Intervensi ini dibagi kedalam 3 kelompok yaitu: ibu hamil, kelompok 0-6 bulan, dan kelompok 7-23 bulan. Umumnya hal tersebut dilakukan oleh sektor kesehatan dan bersifat jangka pendek. ${ }^{2-3}$

Menurut Pedoman Percepatan Gerakan $1000 \mathrm{HPK}$, intervensi gizi spesifik pada ibu hamil berupa suplementasi besi dan folat, pemberian makanan tambahan pada ibu hamil KEK (kekurangan energi kronik), penanggulangan infeksi cacing pada ibu hamil dan pemberian kelambu berinsektisida, serta pengobatan ibu hamil dengan malaria. $^{2}$

Pada masa kehamilan, kebutuhan energi dan asupan gizi pada diet perlu ditingkatkan. Hal ini dilakukan guna mendukung peningkatan metabolisme ibu, volume darah, ekspansi sel darah merah, dan pemberian nutrisi janin. Beberapa mikronutrien yang perlu diperhatikan selama masa kehamilan ialah folat, zat besi, zinc, kalsium, vitamin $\mathrm{D}$, dan asam lemak esensial. Mikronutrien tersebut berfungsi sebagai stimulus pembentukan sel darah merah, perkembangan tulang, dan perkembangan otak. Defisiensi salah satu mikronutrien tersebut dapat menjadi faktor resiko terjadinya anemia. ${ }^{4-5}$

Anemia mengganggu kesehatan ibu hamil dan meningkatkan risiko dampak buruk terhadap ibu hamil maupun janin. Tahun 2011, terdapat 38\% (32,4 juta) ibu hamil usia 15-49 tahun mengalami anemia. Hal ini menunjukkan bahwa proses penurunan kejadian anemia itu mungkin, namun masih lambat untuk mencapai target yang merupakan salah satu dari 6 target gizi global untuk 2025 oleh World Health Assembly yaitu penurunan anemia pada wanita usia reproduktif sebesar $50 \%{ }^{6}$

Menurut World Health Organization (WHO), anemia berdampak pada lebih dari 800 juta anak dan wanita di seluruh dunia. Pada wanita hamil prevalensi anemia sebesar 38,9\% sampai 48,7\%. Angka prevalensi anemia terbesar pada anak dan wanita berada di wilayah Asia Tenggara. ${ }^{3}$ Berdasarkan hasil Survei Kesehatan Rumah Tangga (SKRT) 2001, prevalensi anemia pada ibu hamil di Indonesia $40,1 \%$ dan pada tahun 2007 turun menjadi 24,5\%. Menurut laporan dari Riskesdas 2013, terjadi peningkatan prevalensi anemia pada ibu hamil menjadi $37,1 \%$.

Anemia pada ibu hamil dikaitkan dengan mortalitas dan morbiditas pada ibu dan bayi, termasuk resiko keguguran, stillbirth, prematur, dan berat badan lahir rendah. Selain itu anemia juga saling terkait dengan 5 target gizi secara global yaitu pendek (stunting), BBLR, childhood overweight, ASI eksklusif, dan wasting). ${ }^{6}$

Penyebab tersering anemia ialah defisiensi zat besi, yang diakibatkan ketidakseimbangan cadangan zat besi, tidak adekuatnya asupan besi atau absorpsinya, peningkatan kebutuhan zat besi selama kehamilan atau proses pertumbuhan, dan akibat menstruasi maupun infeksi cacing. ${ }^{6}$

Faktor sosial ekonomi sangat berpengaruh terhadap munculnya anemia pada ibu hamil di negara berkembang. ${ }^{12}$ Menurut penelitian Morsy, prevalensi anemia lebih tinggi pada wanita berpendidikan rendah, wanita dengan jumlah anggota keluarga besar, dan yang tidak menggunakan layanan keluarga berencana. ${ }^{8}$

\section{METODE PENELITIAN}

Jenis penelitian ini ialah analitik dengan desain potong lintang. Pengambilan sampel menggunakan metode total sampling dengan populasi target ibu hamil 
di wilayah Puskesmas Lolak.

Pemeriksaan ini dilakukan dengan melakukan wawancara dengan responden secara langsung menggunakan metode Food Frequency Questionnaire (FFQ) yang terdiri dari 9 kelompok makanan (KM) dengan total sebanyak 86 jenis makanan yang telah disesuaikan dengan jenis makanan lokal masyarakat Provinsi Sulawesi Utara. Data hasil penelitian dimasukkan ke dalam tabel FFQ dan diolah menggunakan Microsoft Excel. Pengambilan data kadar hemoglobin menggunakan alat Rapid Test Hemoglobin meter merek Family $\operatorname{Dr}^{\circledR}$ dan pita ukur untuk pengambilan data LILA.

Data hasil penelitian dimasukkan dalam tabel FFQ dan diolah menggunakan Microsoft Excel serta menggunakan aplikasi SPSS.

\section{HASIL PENELITIAN}

Pada penelitian yang dilaksanakan di Puskesmas Lolak didapatkan 51 responden yang bersedia diwawancara dan dilakukan pengambilan data hemoglobin serta LILA. Responden terbanyak berusia 20-35 tahun yaitu sebanyak 44 orang $(86,7 \%)$ dan responden yang berusia $<20$ dan $>35$ tahun berjumlah 7 responden $(13,7 \%)$ (Tabel 1).

Responden dengan usia kehamilan trimester I merupakan yang paling sedikit yang hanya berjumlah 5 responden $(9,8 \%)$, sedangkan usia kehamilan trimester II dan III memiliki jumlah yang sama yaitu masing-masing berjumlah 23 responden $(45,1 \%)$

Responden dengan usia kehamilan trimester I merupakan yang paling sedikit yang hanya berjumlah 5 responden $(9,8 \%)$, sedangkan usia kehamilan trimester II dan III memiliki jumlah yang sama yaitu masing-masing berjumlah 23 responden $(45,1 \%)$

Distribusi responden berdasarkan riwayat paritas mendapatkan sebanyak 38 responden $(74,5 \%)$ berada pada kategori tidak berisiko terhadap kehamilan karena memiliki anak $\leq 2$ anak sedangkan sisanya, yaitu sebanyak 13 responden $(25,4 \%)$ berada pada kelompok paritas yang berisiko karena memiliki anak berjumlah
$>2$ orang.

Jumlah ibu hamil yang mempunyai jarak aman untuk suatu kehamilan (>2 tahun) lebih besar dibandingkan dengan jumlah ibu hamil dengan jarak kehamilan berisiko dimana terdapat 27 responden $(52,9 \%)$ dengan jarak kehamilan aman dan 24 responden $(47,1 \%)$ berisiko.

Tabel 1. Karakteristik responden

\begin{tabular}{|c|c|c|}
\hline $\begin{array}{c}\text { Karakteristik } \\
\text { responden }\end{array}$ & $\mathbf{n}$ & $\%$ \\
\hline Ibu hamil & 51 & 100 \\
\hline \multicolumn{3}{|l|}{ Usia responden (tahun) } \\
\hline $20-35$ & 44 & 86,7 \\
\hline$<20$ dan $>35$ & 7 & 13,7 \\
\hline \multicolumn{3}{|l|}{ Usia kehamilan } \\
\hline Trimester I & 5 & 9,8 \\
\hline Trimester II & 23 & 45,1 \\
\hline Trimester II & 23 & 45,1 \\
\hline \multicolumn{3}{|l|}{ Riwayat paritas } \\
\hline$\leq 2$ anak & 38 & 74,5 \\
\hline$>2$ anak & 13 & 25,5 \\
\hline \multicolumn{3}{|l|}{ Jarak kehamilan } \\
\hline$<2$ tahun & 27 & 52,9 \\
\hline$\geq 2$ tahun & 24 & 47,1 \\
\hline \multicolumn{3}{|l|}{ Ukuran LILA } \\
\hline$<23,5 \mathrm{~cm}$ & 42 & 82,4 \\
\hline$>23,5 \mathrm{~cm}$ & 9 & 17,6 \\
\hline \multicolumn{3}{|l|}{ Pekerjaan } \\
\hline Ibu rumah tangga & 42 & 82,4 \\
\hline Sekolah & 1 & 2 \\
\hline Pegawai & 5 & 9,8 \\
\hline Wiraswasta & 0 & 0 \\
\hline Petani/nelayan/buruh & 0 & 0 \\
\hline Lainnya & 3 & 5,9 \\
\hline \multicolumn{3}{|l|}{ Pendidikan } \\
\hline Tidak tamat SD/MI & 2 & 3,9 \\
\hline Tamat SD/MI & 11 & 21,6 \\
\hline Tamat SLTP/MTS & 11 & 21,6 \\
\hline Tamat SLTA/MA & 22 & 43,1 \\
\hline Tamat D1/D2/D3/SI & 5 & 9,8 \\
\hline \multicolumn{3}{|l|}{ Pendapatan } \\
\hline >UMP & 22 & 43,1 \\
\hline <UMP & 29 & 56,9 \\
\hline
\end{tabular}

Dari 51 responden hanya terdapat 9 responden $(17,6 \%)$ yang tergolong berisiko terhadap kekurangan energi kronis (KEK) atau memiliki ukuran LILA $<23,5 \mathrm{~cm}$. Sebanyak 42 responden $(82,4 \%)$ tidak berisiko terhadap KEK karena ukuran LILA $>23,5 \mathrm{~cm}$. 
Pada distribusi ibu hamil berdasarkan pekerjaan didapatkan sebanyak 42 responden $(82,4 \%)$ tidak bekerja. Terdapat 1 responden $(2 \%)$ yang masih sekolah, pegawai 5 responden $(9,8 \%)$, lainnya 3 responden $(5,9 \%)$, sedangkan untuk kategori wiraswasta dan petani/nelayan/buruh tidak ada.

Distribusi pendidikan responden di Puskesmas Lolak sangat bervariasi, paling banyak pendidikan terakhir ibu hamil yaitu SMA berjumlah 22 orang $(43,1 \%)$, diikuti dengan pendidikan akhir SD dan SMP, masing-masing berjumlah 11 orang $(21,6 \%)$, perguruan tinggi 5 orang $(9,8 \%)$, dan terdapat 2 orang $(3,9 \%)$ yang tidak tamat SD.

Pendapatan keluarga dinilai berdasarkan kategori di atas dan di bawah Upah Minimum Provinsi (UMP) Sulawesi Utara. Berdasarkan hasil penelitian, ditemukan bahwa, terdapat 29 ressponden dengan pendapatan keluarga <UMP yaitu sebanyak $29(56,9 \%)$ dan Ibu Hamil yang pendapatan >UMP sebanyak $22(43,1 \%)$.

Dari 51 reponden, terdapat 48 respoden $(94,1 \%)$ memiliki kadar hemoglobin $<11 \mathrm{~g} / \mathrm{dl}$ dan hanya 3 responden dengan kadar hemoglobin >11g/dl (Tabel 2).

Tabel 2. Distribusi responden berdasarkan kadar hemoglobin

\begin{tabular}{ccc}
\hline $\begin{array}{c}\text { Kadar } \\
\text { hemoglobin }\end{array}$ & n (\%) & Min-max \\
\hline$<11 \mathrm{~g} / \mathrm{dl}$ & $48(94,1 \%)$ & $6,3-11,7$ \\
$>11 \mathrm{~g} / \mathrm{dl}$ & $3(5,9 \%)$ & \\
\hline
\end{tabular}

Data hasil penelitian mendapatkan bahwa beras merupakan bahan makanan yang paling sering dikonsumsi responden, yaitu sebanyak 43 responden $(84,31 \%)$, diikuti dengan ikan air laut yaitu sebanyak 30 responden $(58,82 \%)$ sedangkan ayam hanya sering dikonsumsi oleh 3 responden $(5,88 \%)$ (Tabel 3).

Distribusi frekuensi tertingi bahan makanan yang jarang dikonsumsi responden terbanyak ialah kelapa muda sebanyak 47 responden $(92,16 \%)$. Roti dan pepaya merupakan bahan makanan kedua yang dikonsumsi sebagian besar responden dalam frekuensi jarang, yaitu sebanyak 39 orang $(76,47 \%)$ (Tabel 4).

Tabel 3. Distribusi frekuensi tertinggi bahan makanan yang sering dikonsumsi berdasarkan kelompok makanan FFQ

\begin{tabular}{cccc}
\hline \multirow{2}{*}{ KM } & \multicolumn{2}{c}{ Frekuensi } & \\
\cline { 2 - 3 } FFQ & $\mathrm{n}$ & $\%$ & \\
\hline I & 43 & 84,31 & Beras \\
II & 10 & 19,61 & Tahu \\
III & 3 & 5,88 & Ayam \\
IV & 30 & 58,82 & Ikan Air Laut \\
V & 20 & 39,22 & Kangkung \\
VI & 9 & 17,65 & Telur Ayam \\
VII & 8 & 15,69 & Pisang \\
VIII & 19 & 37,25 & Minyak Kelapa \\
IX & 25 & 50,98 & Garam Dapur \\
\hline
\end{tabular}

Tabel 4. Distribusi frekuensi tertinggi bahan makanan yang jarang dikonsumsi berdasarkan kelompok makanan FFQ

\begin{tabular}{|c|c|c|c|}
\hline \multirow{2}{*}{ KM } & \multicolumn{2}{|c|}{ Frekuensi } & \multirow{2}{*}{ Bahan makanan } \\
\hline & $\mathrm{n}$ & $\%$ & \\
\hline I & 39 & 76,47 & Roti \\
\hline II & 47 & 92,16 & Kelapa muda \\
\hline III & 38 & 74,51 & Ayam \\
\hline IV & 25 & 49,02 & Ikan air tawar \\
\hline V & 29 & 56,86 & Bayam \\
\hline VI & 36 & 70,59 & Telur ayam \\
\hline VII & 39 & 76,47 & Pepaya \\
\hline VIII & 31 & 60,78 & Minyak kelapa \\
\hline IX & 28 & 54,90 & Gula pasir \\
\hline
\end{tabular}

Dari total 51 responden, terdapat 50 responden tidak pernah mengonsumsi kelapa tua, emping melinjo, corned beef, daging kambing, dan telur asin $(98,04 \%)$, diikuti dengan bengkoang dan pare yang tidak pernah dikonsumsi oleh 49 responden $(96,8 \%)$. Jenis bahan makanan yang paling rendah untuk kategori tidak pernah ialah kentang, yaitu 41 responden $(41,18 \%)$ (Tabel 5).

Berdasarkan olah statistik rata-rata konsumsi makanan per-hari, dapat dilihat bahwa beras merupakan bahan makanan yang paling banyak dikonsumsi reposnden per-harinya yaitu sebanyak 347,48gr/hari, diikuti kelapa muda sebanyak 275,22gr/hari dan ikan air laut dengan jumlah rata-rata 172,17gr/hari (Tabel 6). Emping melinjo merupakan bahan makanan yang paling 
sedikit konsumsi rata-rata dengan hanya 0,03gr/hari (Tabel 7).

Tabel 5. Distribusi frekuensi tertinggi bahan makanan yang tidak pernah dikonsumsi berdasarkan kelompok makanan FFQ

\begin{tabular}{cccc}
\hline \multirow{2}{*}{ KM } & \multicolumn{2}{c}{ Frekuensi } & Bahan makanan \\
\cline { 2 - 3 } & $\mathrm{n}$ & $\%$ & \\
\hline I & 41 & 41,18 & Kentang \\
II & 50 & 98,04 & Kelapa tua \\
II & 50 & 98,04 & Emping melinjo \\
III & 50 & 98,04 & Corned beef \\
III & 50 & 98,04 & Daging kambing \\
IV & 40 & 78,43 & Kepiting \\
V & 49 & 96,08 & Bengkoang \\
V & 49 & 96,08 & Pare \\
VI & 50 & 98,04 & Telur bebek asin \\
VII & 44 & 86,27 & Manggis \\
VIII & 48 & 94,12 & Yogurt \\
IX & 46 & 90,2 & Sirup \\
\hline
\end{tabular}

Tabel 6. Rerata konsumsi bahan makanan tertinggi berdasarkan kelompok makanan FFQ

\begin{tabular}{ccc}
\hline KM & (gr/hari) & Bahan makanan \\
\hline I & 347,48 & Beras \\
II & 275,22 & Kelapa muda \\
III & 16,32 & Ayam \\
IV & 172,17 & Ikan air laut \\
V & 141,20 & Tomat masak \\
VI & 50,74 & Telur ayam \\
VII & 148,72 & Mangga \\
VIII & 149,26 & Minyak kelapa \\
IX & 24,56 & Gula pasir \\
\hline
\end{tabular}

Tabel 7. Rata-rata konsumsi bahan makanan terendah berdasarkan kelompok makanan FFQ

\begin{tabular}{ccc}
\hline KM & (gr/hari) & Bahan makanan \\
\hline I & 35,53 & Mie \\
II & 0,03 & Emping melinjo \\
III & 0,07 & Kentang \\
IV & 1,23 & Belut \\
V & 0,07 & Pare \\
VI & 0,14 & Telur Puyuh \\
VII & 2,72 & Langsat/Duku \\
VIII & 0,66 & Mentega \\
IX & 0,24 & Gula Kelapa \\
\hline
\end{tabular}

Berdasarkan hasil penelitian didapatkan bahwa beras merupakan bahan makanan sumber karbohidrat yang paling banyak dikonsumsi, yaitu sebesar 347,48gr/hari.
Ikan air laut merupakan bahan makanan protein yang paling banyak dikonsumsi responden, yaitu dengan rerata sebesar 272,22gr/hari. Minyak kelapa sebagai sumber lemak, yaitu sebanyak 149,26gr/ hari (Tabel 8).

Tabel 8. Rerata konsumsi bahan maknan tertinggi berdasarkan zat gizi makro

\begin{tabular}{lcc}
\hline \multicolumn{1}{c}{ Zat gizi } & $\begin{array}{c}\text { Rata-rata } \\
\text { (gr/hari) }\end{array}$ & Bahan makanan \\
\hline Karbohidrat & 347,48 & Beras \\
Protein & 272,22 & Ikan air laut \\
Lemak & 149,26 & Minyak kelapa \\
\hline
\end{tabular}

Responden paling banyak mengonsumsi makanan yang mengandung karbohidrat, yaitu sebesar 330,97gr/hari. Bahan makanan yang mengandung protein dikonsumsi sebanyak 236,15g/hari sedangkan bahan makanan yang mengandung lemak hanya dikonsumsi responden sebesar 153,82gr/ hari (Tabel 9).

Tabel 9. Rerata konsumsi bahan makanan responden berdasarkan zat gizi makro

\begin{tabular}{cc}
\hline Zat gizi & Rerata $($ gr/hari) \\
\hline Karbohidrat & 330,03 \\
Protein & 236,15 \\
Lemak & 153,82 \\
\hline
\end{tabular}

Hasil analisis hubungan antara usia dan kadar hemoglobin mendapatkan sebanyak 41 responden $(80,4 \%)$ dari kelompok usia tidak berisiko (20-35 tahun) memiliki kadar hemoglobin $<11 \mathrm{~g} / \mathrm{dl}$ dibandingkan dengan kelompok yang sama namun dengan kadar hemoglobin $>11 \mathrm{~g} / \mathrm{dl}$ sebanyak 3 responden $(5,9 \%)$. Hasil uji statistik mendapatkan nilai $P=0,476$, sehingga dapat disimpulkan bahwa tidak terdapat hubungan bermakna antara usia responden dan kadar hemoglobin (Tabel 10)

Hasil analisis antara usia kehamilan dan kadar hemoglobin menunjukkan bahwa proporsi kadar hemoglobin $<11 \mathrm{~g} / \mathrm{dl}$ pada responden dengan usia kehamilan trimester III ialah 23 responden $(45,1 \%)$ dan trimester II sebanyak 21 responden $(41,2 \%)$. Berdasarkan uji statistik diperoleh nilai 
$P=0,439$, sehingga dapat disimpulkan tidak terdapat hubungan bermakna antara proporsi kadar hemoglobin pada responden dan usia kehamilan trimester I dan III serta trimester II (Tabel 10)

Untuk variabel paritas, proporsi kadar hemoglobin $<11 \mathrm{~g} / \mathrm{dl}$ pada kelompok tidak berisiko ( $\leq 2$ orang) didapatkan proporsi kadar hemoglobin <11g/dl sebanyak 36 responden $(70,6 \%)$ dan yang memiliki kadar hemoglobin $>11 \mathrm{~g} / \mathrm{dl}$ pada kelompok ini ialah 2 responden $(3,9 \%)$. Pada kelompok berisiko ( $>2$ orang), proporsi kadar hemoglobin $<11 \mathrm{~g} / \mathrm{dl}$ juga lebih besar, yaitu 12 responden $(23,5 \%)$ dibandingkan pada kelompok yang sama namun dengan kadar hemoglobin $>11 \mathrm{~g} / \mathrm{dl}$ terdapat 1 responden $(2 \%)$. Hasil uji statistik pada variabel riwayat paritas ini menunjukkan tidak terdapat hubungan bermakna antara riwayat paritas dan kadar hemoglobin, dengan nilai $P=0,748$ (Tabel 10).

Hasil analisis hubungan antara jarak kehamilan dan kadar hemoglobin responden secara statistik juga tidak menunjukan hubungan bermakna dengan nilai $P=0,483$, dimana proporsi kadar hemoglobin $<11 \mathrm{~g} / \mathrm{dl}$ pada jarak kehamilan berisiko ( $\leq 2$ tahun) sebanyak 26 responden (51\%) diikuti dengan kelompok jarak kehamilan tidak berisiko ( $>2$ tahun) yang terdapat 22 responden $(43,1 \%)$ (Tabel 10$)$.

Hasil analisis hubungan LILA dengan kadar hemoglobin tidak menunjukkan hubungan bermakna secara statistik dengan nilai $P=0,409$. Perbedaan kadar hemoglobin $<11 \mathrm{~g} / \mathrm{dl}$ dengan LILA $<23,5 \mathrm{~cm}$ yang berjumlah 9 responden $(17,6 \%)$ lebih kecil dibandingkan dengan kelompok LILA $\geq 23,5 \mathrm{~cm}$ dengan jumlah responden sebanyak 39 orang $(76,5 \%)$ (Tabel 10$)$

Analisis statistik untuk hubungan pekerjaan dan kadar hemoglobin mendapatkan nilai $P=0,877$. Tidak terdapat hubungan bermakna antara pekerjaan dan kadar hemoglobin. Kategori ibu rumah tangga memiliki jumlah terbanyak, yaitu 39 reponden $(76,5 \%)$ dengan kadar hemoglobin $<11 \mathrm{~g} / \mathrm{dl}$ (Tabel 10).

Hasil analisis hubungan antara tingkat pendidikan dan kadar hemoglobin menun- jukkan bahwa sebanyak 19 responden $(37,3 \%)$ tamat SLTA memiliki kadar hemoglobin $<11 \mathrm{~g} / \mathrm{dl}$, diikuti dengan tingkat pendidikan tamat SD dan tamat SLTP, masing-masing sebanyak 11 responden $(21,6 \%)$. Berdasarkan hasil uji statistik didapatkan nilai $P=0,379$ yang menunjukkan tidak terdapat hubungan bermakna antara tingkat pendidikan dan kadar hemoglobin (Tabel 10).

Pada hasil analisis hubungan pendapatan keluarga dan kadar hemoglobin didapatkan bahwa responden dengan tingkat pendapatan keluarga <UMP dan kadar hemoglobin <11g/dl sebanyak 27 responden $(52,9 \%)$ sedangkan pada tingkat pendapatan >UMP dan kadar hemoglobin < $11 \mathrm{~g} / \mathrm{dl}$ sejumlah 21 responden $(41,2 \%)$. Hasil uji statistik mendapatkan nilai $P=0,724$, sehingga dapat disimpulkan bahwa tidak terdapat hubungan bermakna antara pendapatan keluarga dan kadar hemoglobin responden (Tabel 10).

Berdasarkan hasil analisis hubungan antara kelompok kacang-kacangan dan kadar hemoglobin ditemukan bahwa 38 responden $(74,5 \%)$ yang sering mengonsumsi sumber protein berasal dari kelompok kacang-kacangan memiliki kadar hemoglobin $<11 \mathrm{~g} / \mathrm{dl}$. Hasil uji statistik mendapatkan nilai $P=0,378$, yang menunjukkan bahwa tidak terdapat hubungan bermakna antara frekuensi konsumsi kacang-kacangan sumber protein dan kadar hemoglobin (Tabel 11).

Hasil analisis hubungan antara kelompok ikan dan kadar hemoglobin, menunjukkan bahwa 42 responden $(82,4 \%)$ masuk dalam kategori sering dengan memiliki kadar hemoglobin $<11 \mathrm{~g} / \mathrm{dl}$. Hanya 2 responden $(3,9 \%)$ dari kategori ini yang memiliki kadar hemoglobin $>11 \mathrm{~g} / \mathrm{dl}$. Melalui uji statistik didapatkan nilai $P=1,645$, sehingga dapat disimpulkan tidak terdapat hubungan bermakna antara frekuensi konsumsi ikan dan kadar hemoglobin (Tabel 11).

Berdasarkan hasil analisis hubungan antara frekuensi konsumsi protein kelompok telur dan kadar hemoglobin, didapatkan 31 responden masuk dalam kategori 
jarang dan memiliki kadar hemoglobin kategori yang sama dan memiliki kadar $<11 \mathrm{~g} / \mathrm{dl}$ dan hanya 2 responden dengan hemoglobin $>11 \mathrm{~g} / \mathrm{dl}$ (Tabel 11).

Tabel 10. Hubungan antara usia responden, usia kehamilan, riwayat paritas, jarak kehamilan, ukuran LILA, status pekerjaan, pendidikan, dan pendapatan keluarga dengan kadar hemoglobin responden

\begin{tabular}{|c|c|c|c|c|c|c|c|}
\hline \multirow{3}{*}{ Variabel } & \multicolumn{6}{|c|}{ Kadar hemoglobin } & \multirow{3}{*}{$\mathbf{P}^{(\alpha=0,05)}$} \\
\hline & \multicolumn{2}{|c|}{$<11 \mathrm{~g} / \mathrm{dl}$} & \multicolumn{2}{|c|}{$>11 \mathrm{~g} / \mathrm{dl}$} & \multicolumn{2}{|c|}{ Total } & \\
\hline & $\mathrm{n}$ & $\%$ & $\mathrm{n}$ & $\%$ & $\mathrm{n}$ & $\%$ & \\
\hline \multicolumn{8}{|l|}{ Usia responden } \\
\hline 20-35 tahun & 41 & 80,4 & 3 & 5,9 & 44 & 86,3 & 0,476 \\
\hline$<20 \&>35$ tahun & 7 & 13,7 & 0 & 0 & 7 & 13,7 & \\
\hline \multicolumn{8}{|l|}{ Usia kehamilan } \\
\hline Trimester I & 4 & 7,8 & 1 & 2,0 & 5 & 9,8 & \\
\hline Trimester II & 21 & 41,2 & 2 & 3,9 & 23 & 45,1 & 0,168 \\
\hline Trimester III & 23 & 45,1 & 0 & 0 & 23 & 45,1 & \\
\hline \multicolumn{8}{|l|}{ Paritas } \\
\hline$\leq 2$ anak & 36 & 70,6 & 2 & 3,9 & 38 & 74,5 & \multirow[b]{2}{*}{0,748} \\
\hline$>2$ Anak & 12 & 23,5 & 1 & 2,0 & 13 & 25,5 & \\
\hline \multicolumn{8}{|l|}{ Jarak kehamilan } \\
\hline$\leq 2$ tahun & 26 & 51,0 & 1 & 2,0 & 27 & 52,9 & \multirow{2}{*}{0,483} \\
\hline$>2$ tahun & 22 & 43,1 & 2 & 3,9 & 24 & 47,1 & \\
\hline \multicolumn{8}{|l|}{ Ukuran LILA } \\
\hline$<23,5 \mathrm{~cm}$ & 9 & 17,6 & 0 & 0 & 9 & 17,6 & \multirow{2}{*}{0,409} \\
\hline$\geq 23,5 \mathrm{~cm}$ & 39 & 76,5 & 3 & 5,9 & 42 & 82,4 & \\
\hline \multicolumn{8}{|l|}{ Status pekerjaan } \\
\hline Tidak bekerja & 39 & 76,5 & 3 & 5,9 & 42 & 82,4 & \multirow{4}{*}{0,877} \\
\hline Sekolah & 1 & 2,0 & 0 & 0 & 1 & 2,0 & \\
\hline Pegawai & 5 & 9,8 & 0 & 0 & 5 & 9,8 & \\
\hline Lainnya & 3 & 5,9 & 0 & 0 & 3 & 5,9 & \\
\hline \multicolumn{8}{|l|}{ Pendidikan } \\
\hline Tidak tamat SD & 2 & 3,9 & 0 & 0 & 2 & 3,9 & \multirow{5}{*}{0,379} \\
\hline Tamat SD/MI & 11 & 21,6 & 0 & 0 & 11 & 21,6 & \\
\hline Tamat SLTP/MTS & 11 & 21,6 & 0 & 0 & 11 & 21,6 & \\
\hline Tamat SLTA/MA & 19 & 37,3 & 3 & 5,9 & 22 & 43,1 & \\
\hline Tamat D1/D2/D3/SI & 5 & 9,8 & 0 & 0 & 5 & 9,8 & \\
\hline \multicolumn{8}{|l|}{ Pendapatan keluarga } \\
\hline >UMP & 21 & 41,2 & 1 & 2,0 & 22 & 43,1 & \multirow{2}{*}{0,724} \\
\hline$<\mathrm{UMP}$ & 27 & 52,9 & 2 & 3,9 & 29 & 56,9 & \\
\hline
\end{tabular}

Tabel 11. Hubungan antara kelompok bahan makanan sumber protein dengan kadar hemoglobin

\begin{tabular}{|c|c|c|c|c|c|c|c|}
\hline \multirow{3}{*}{ KM } & \multicolumn{4}{|c|}{$\begin{array}{c}\text { Frekuensi konsumsi protein sering, } \\
\text { jarang, tidak pernah per-hari }\end{array}$} & \multirow{2}{*}{\multicolumn{2}{|c|}{ Total }} & \multirow{3}{*}{$P^{(\alpha=0,05)}$} \\
\hline & \multicolumn{2}{|c|}{$<11 \mathrm{~g} / \mathrm{dl}$} & \multicolumn{2}{|c|}{$>11 \mathrm{~g} / \mathrm{dl}$} & & & \\
\hline & $\mathrm{n}$ & $\%$ & $\mathrm{n}$ & $\%$ & $\mathrm{n}$ & $\%$ & \\
\hline \multicolumn{8}{|l|}{ II Kacang-kacangan } \\
\hline Sering & 38 & 74,5 & 3 & 7,3 & 41 & 80,4 & \multirow{3}{*}{0,378} \\
\hline Jarang & 10 & 19,6 & 0 & 0 & 10 & 19,6 & \\
\hline Tidak pernah & 0 & 0 & 0 & 0 & 0 & 0 & \\
\hline \multicolumn{7}{|l|}{ III Daging } & \multirow{4}{*}{0,580} \\
\hline Sering & 9 & 17,6 & 0 & 0 & 9 & 17,6 & \\
\hline Jarang & 35 & 68,6 & 3 & 7,9 & 38 & 74,6 & \\
\hline Tidak pernah & 4 & 7,8 & 0 & 0 & 4 & 7,8 & \\
\hline \multicolumn{7}{|l|}{ IV Ikan } & \multirow{4}{*}{0,481} \\
\hline Sering & 42 & 82,4 & 2 & 3,9 & 44 & 86,2 & \\
\hline Jarang & 5 & 9,8 & 1 & 2,0 & 6 & 11,8 & \\
\hline Tidak pernah & 1 & 2 & 0 & 0 & 1 & 2 & \\
\hline \multicolumn{7}{|l|}{ VI Telur } & \multirow{4}{*}{0,366} \\
\hline Sering & 12 & 23,5 & 0 & 0 & 12 & 23,5 & \\
\hline Jarang & 31 & 60,8 & 2 & 3,9 & 33 & 64,8 & \\
\hline Tidak pernah & 5 & 9,8 & 1 & 2,0 & 6 & 11,7 & \\
\hline
\end{tabular}




\section{BAHASAN}

Reponden pada penelitian ini ialah ibu hamil yang datang dan bersedia di wawancara dan dilakukan pemeriksaan dan didapatkan 51 responden ibu hamil. Sebelum dilakukan uji statistik untuk melihat hubungan antara variabel, dilakaukan analisis normalitas untuk menguji data variabel bebas dan data variabel terikat pada persamaan regresi yang dihasilkan, berdistribusi normal atau tidak normal. Dalam penelitian ini dilakukan uji normalitas dengan cara Kolomogorov-Smirnov. Data yang berdistribusi normal ditunjukkan dengan nilai $P>0,05$ atau 5\%. ${ }^{9}$ Dalam penelitian ini didapatkan nilai $P<0,05$ yang berarti data dalam penelitian ini terdistribusi dengan tidak normal. Hal ini dapat terjadi akibat pada penelitian ini jumlah sampel hanya sedikit yaitu 51 responden, dan perbandingan antara case dan non case terlampau jauh sehingga tidak bermakna secara statistik.

\section{Kadar hemoglobin ibu hamil}

Kadar hemoglobin merupakan salah satu indikator untuk menentukan terjadinya anemia. Pada penelitian ini digunakan alat hemoglobin meter dengan mengambil darah kapiler jari ibu hamil. Cara ini digunakan karena harga yang lebih terjangkau dan lebih mudah dilaksanakan di lokasi penelitian.

Hasil penelitian ini memperlihatkan bahwa dari 51 responden, sebagian besar responden $(94,1 \%)$ menderita anemia, karena kadar hemoglobin <11g/dl dan hanya 3 responden $(5,9 \%)$ yang tidak menderita anemia.

Kondisi anemia dapat meningkatkan risiko kematian ibu pada saat melahirkan, melahirkan bayi dengan berat badan lahir rendah, janin dan ibu mudah terkena infeksi, keguguran, dan meningkatkan risiko bayi lahir prematur. Di Afrika dan Asia, anemia diperkirakan berkontribusi lebih dari 115000 kematian ibu dan 591 000 kematian perinatal secara global per tahun. Konsekuensi morbiditas terkait dengan anemia kronis memperpanjang hilangnya produktivitas dari kapasitas gangguan kerja, gangguan kognitif, dan peningkatan kerentanan terhadap infeksi, yang juga memberikan beban ekonomi. ${ }^{10}$

\section{Hubungan kadar hemoglobin dan usia ibu hamil}

Usia ibu hamil merupakan salah satu faktor risiko anemia pada masa kehamilan. Ibu yang berusia $<20$ tahun dan $>35$ tahun, bila hamil memiliki resiko yang membahayakan kesehatan dan keselamatan ibu itu sendiri maupun janinnya. Ibu yang melahirkan pada usia ekstrim (terlalu muda dan terlalu tua) berisiko mengalami perdarahan yang dapat menyebabkan anemia. $^{11}$

Hasil penelitian mendapatkan $80,3 \%$ ibu hamil dengan kadar hemoglobin $<11 \mathrm{~g} / \mathrm{dl}$ berada pada usia yang tidak berisiko (20-35 tahun) sedangkan pada usia yang berisiko $(<20$ dan $>35$ tahun $)$ didapatkan hanya $13,7 \%$. Hasil uji statistik mendapatkan nilai $P>0,05$, yang berarti tidak terdapat hubungan bermakna antara usia ibu dan kadar hemoglobin. Hasil ini serupa dengan penelitian Purwaningtyas dan Galuh di Puskesmas Karang Anyar Kota Semarang yang menunjukkan bahwa tidak terdapat hubungan antara usia dan kejadian anemia pada ibu hamil $(P=$ 1,000). ${ }^{12}$ Namun hal ini tidak sejalan dengan penelitian di Eastern Ethiopia yang menyatakan terdapat hubungan antara usia ibu $>35$ tahun dan hemoglobin dengan nilai $P=0,007$. Hal ini mungkin disebabkan karena pada peningkatan usia dapat terjadi kehilangan micronutrient yang bisa merujuk pada kurang gizi dan anemia. ${ }^{13}$ Selain itu, hasil penelitian yang dilakukan di Southeast Ethiopia menyatakan bahwa prevalensi anemia lebih tinggi (34,5\%) pada wanita hamil dengan kelompok usia 18-26 tahun; hal ini menunjukkan bahwa semua kelompok usia ibu berpengaruh terhadap anemia. ${ }^{14}$

\section{Kadar hemoglobin dan usia kehamilan ibu hamil}

Kebutuhan zat gizi pada ibu hamil terus meningkat sesuai dengan bertambahnya usia kehamilan, salah satunya zat besi. 
Selama kehamilan terjadi pengenceran (hemodilusi) yang terus bertambah sesuai dengan umur kehamilan, dimana terjadi saat proses konsepsi dan puncaknya terjadi pada usia kehamilan 32- 34 minggu. ${ }^{15}$

Hasil penelitian mendapatkan jumlah responden dengan usia kehamilan trimester III yang memiliki kadar hemoglobin $<11 \mathrm{~g} / \mathrm{dl}$ sejumlah 23 responden $(45,1 \%)$. Penelitian oleh Bedi et al. ${ }^{16}$ mendapatkan 91,3\% anemia terjadi pada usia kehamilan trimes-ter III sedangkan pada responden dengan usia kehamilan trimester II pada penelitian ini yang memiliki kadar hemoglobin $<11 \mathrm{~g} / \mathrm{dl}$ berjumlah 21 responden $(41,2 \%)$.

Menurut penelitian Obai et al. ${ }^{17}$ prevalensi anemia tertinggi ditemukan pada trimester III $(24,3 \%)$ dibandingkan dengan trimester I $(14,6 \%)$ dan II $(20,7 \%)$. Meningkatnya hemodilusi pada ujung trimester II menjelaskan mengapa lebih banyak anemia terjadi pada usia kehamilan trimester III.

\section{Kadar hemoglobin dan riwayat paritas}

Paritas merupakan jumlah kehamilan yang bayinya berhasil hidup $\geq 20$ minggu. Hasil penelitian paritas mendapatkan jumlah responden riwayat paritas dengan $>2$ anak dan kadar hemoglobin $<11 \mathrm{~g} / \mathrm{dl}$ hanya $23,5 \%$ sedangkan responden dengan riwayat paritas $\leq 2$ anak dan kadar hemoglobin $<11 \mathrm{~g} / \mathrm{dl}$ berjumlah $70,6 \%$. Uji statistik menunjukkan nilai $P=0,748$ yang mennunjukkan tidak terdapat hubungan bermakna antara riwayat paritas dan kadar hemoglobin. Hasil penelitian tersebut selaras dengan penelitian Purwaningtyas di Puskesmas Karang Anyar Kota Semarang yang mendapatkan nilai $P=0,675 .{ }^{12}$

Hal ini tidak selaras dengan pendapat Manuaba, ${ }^{18}$ bahwa semakin sering wanita mengalami kehamilan dan kelahiran akan makin banyak kehilangan zat besi dan menjadi anemis. Jika persediaan zat besi minimal, maka setiap kehamilan akan menguras persediaaan zat besi tubuh dan akhirnya menimbulkan anemia pada kehamilan berikutnya.
Kadar hemoglobin dan jarak kehamilan

Jarak kehamilan sangat memengaruhi status anemia gizi besi pada wanita hamil. Hal ini disebabkan karena pada saat kehamilan cadangan besi yang ada ditubuh akan terkuras untuk memenuhi kebutuhan zat besi selama kehamilan terutama pada ibu hamil yang mengalami kekurangan cadangan besi. Pada awal kehamilan dan pada saat persalinan wanita hamil juga banyak kehilangan zat besi melalui perdarahan. Dibutuhkan waktu untuk memulihkan cadangan besi yang ada di dalam tubuh, waktu yang paling baik untuk memulihkan kondisi fisiologik ibu ialah dua tahun. ${ }^{18}$

Hasil penelitian ini didukung oleh penelitian yang dilakukan oleh Handayani ${ }^{19}$ yang menyatakan bahwa tidak terdapat hubungan bermakna antara jarak kehamilan dan kejadian anemia. Demikian juga dengan penelitian Prahesti ${ }^{20}$ yang menyatakan bahwa berdasarkan perhitungan variabel jarak kehamilan diperoleh nilai korelasi antara jarak kehamilan dan anemia sebesar $P=0,402 \quad(P>0,05) \quad$ yang berarti tidak terdapat hubungan antara jarak kehamilan dan anemia.

\section{Kadar hemoglobin dan ukuran lila}

Ukuran LILA menggambarkan status gizi ibu hamil dan untuk mengetahui risiko KEK atau gizi kurang. Ambang batas LILA WUS dengan risiko KEK di Indonesia ialah $<23,5 \mathrm{~cm}$. Bila ukuran LILA $\geq 23,5 \mathrm{~cm}$ maka tidak beresiko KEK. ${ }^{12}$

Uji statistik untuk variabel LILA menunjukkan bahwa kadar hemoglobin $<11 \mathrm{~g} / \mathrm{dl}$ lebih banyak pada responden dengan ukuran LILA $\geq 23,5 \mathrm{~cm}(76,5 \%)$ dibandingkan dengan ukuran LILA $<23,5$ $(17,6 \%)$. Didapatkan juga nilai $P=0,409$, yang berarti tidak terdapat hubungan yang sigfikan antara ukuran LILA dan kadar hemoglobin.

Kemungkinan terjadinya anemia walaupun ukuran LILA $\geq 23,5 \mathrm{~cm}$ dikarenakan terdapat faktor-faktor lain yang dapat menyebabkan anemia seperti asupan zat besi yang kurang. Sebesar dua per tiga zat besi dalam tubuh terdapat dalam sel darah merah hemoglobin. Faktor-faktor 
lain yang berpengaruh terhadap kejadian anemia antara lain gaya hidup seperti merokok, minum minuman keras, kebiasaan sarapan pagi, keadaan ekonomi, demografi, pendidikan, usia, jenis kelamin, dan wilayah. Selain itu juga LILA bukanlah satu-satunya metode untuk mengukur status gizi ibu hamil karena anemia merupakan keadaan yang tidak normal dan harus dicari penyebabnya. Anamnesis, pemeriksaan fisik dan, pemeriksaan laboratorium sederhana berguna dalam evaluasi penderita anemia. $^{21}$

\section{Kadar hemoglobin dan status pekerjaan}

Ibu rumah tangga (IRT) yang tidak mempunyai pekerjaan merupakan salah satu faktor risiko terjadinya anemia karena sebagian besar ibu rumah tangga pendapatannya bergantung pada suami untuk memenuhi kebutuhan mereka, Sebagian IRT tersebut berstatus sosial ekonomi rendah. Anemia ditemukan pada wanita yang pendapatan bulanannya rendah. ${ }^{17}$

Dari hasil analisis diketahui anemia lebih banyak terjadi pada responden dengan status tidak bekerja $(76,5 \%)$ dan hanya sebagian kecil responden $(17,7 \%)$ yang bekerja menderita anemia. Hasil penellitian juga menunjukkan nilai $P>0,05$, yang berarti bahwa tidak terdapat hubungan bermakna antara status pekerjaan dan kejadian anemia.

Penelitian oleh Aisyah $^{22}$ juga menunjukkan tidak terdapat hubungan bermakna antara status pekerjaan dan kejadian anemia $(P=0,449)$. Demikian juga dengan penelitian oleh Ngurah $\mathrm{Rai}^{23}$ di Kota Manado yang juga menunjukkan tidak terdapat hubungan bermakna antara kedua variabel.

Hasil penelitian ini tidak sejalan dengan pendapat Bedi et al. ${ }^{16}$ mengenai pekerjaan dikaitkan dengan anemia pada kehamilan. Perempuan yang tidak bekerja cenderung memiliki status sosial ekonomi yang lebih rendah sehingga harus bekerja lebih keras pada masa kehamilan. Hal ini sangat berdampak kepada ibu hamil sehingga memiliki nutrisi buruk, jarak kelahiran pendek, dan kunjungan antenatal care rendah.

\section{Kadar hemoglobin dan tingkat pendi- dikan}

Dari hasil penelitian untuk tingkat pendidikan didapatkan nilai $P>0,05$ yang menunjukkan tidak terdapat hubungan bermakna tingkat pendidikan dan kejadian anemia pada ibu hamil.

Hasil penelitian ini sejalan dengan penelitian yang dilakukan oleh Ernawatik ${ }^{26}$ di Puskesmas Karanganyar yang menunjukkan tidak terdapat hubungan bermakna $(P=1,000)$ antara pendidikan dan kejadian anemia ibu hamil. Demikian juga dengan penelitian Ngurah $\mathrm{Rai}^{23}$ di Kota Manado yang menyatakan hal serupa.

Hal ini tidak sejalan dengan penelitian Lokare $^{25}$ di Aurangabad India yang menyatakan terdapat hubungan antara tingkat pendidikan dan kejadian anemia dimana anemia meningkat beriringan dengan menurunnya tingkat pendidikan.

Tingkat pendidikan ibu hamil berhubungan dengan tingkat pengetahuannya. Rendahnya pendidikan ibu memengaruhi penerimaan informasi sehingga pengetahuan tentang zat besi menjadi terbatas. Semakin tinggi tingkat pendidikan seseorang, semakin mudah menerima informasi. $^{26}$

\section{Kadar hemoglobin dan pendapatan keluarga}

Dari hasil analisis, diketahui bahwa proporsi kejadian anemia banyak terjadi pada responden dengan tingkat ekonomi rendah atau <UMP Provinsi Sulawesi Utara tahun 2017 yaitu sebanyak 52,9\% dari total $56,9 \%$.

Menurut Bekele et al. ${ }^{4}$ yang melakukan penelitian di Ethiopia, menyatakan bahwa pendapatan tiap bulan secara bermakna berhubungan dengan kejadian anemia pada masa kehamilan. Hal ini dijelaskan dengan fakta bahwa orang Ethiopia menahabiskan $57 \%$ pengeluaran untuk makanan. sehingga jika seorang wanita hamil dengan kondisi pendapatan rendah menjadi sulit untuk mendapatkan nutrisi yang adekuat dan berisiko terjadi anemia. 


\section{Kadar hemoglobin dan pola konsumsi}

Berdasarkan Pedoman Gizi Seimbang (2014), karbohidrat, protein, dan lemak merupakan zat gizi makro yang dibutuhkan saat masa kehamilan. ${ }^{27}$ Hasil penelitian pola konsumsi dengan menggunakan Food Frequency Questionnair (FFQ) yang berisi 86 jenis bahan makanan menunjukkan hasil dari kelompok sumber karbohidrat, beras merupakan bahan makanan sumber karbohidrat yang paling sering dikonsumsi oleh ibu hamil di Lolak. Hal ini sesuai dengan penelitian Narasiang et al. ${ }^{28}$ yang menyatakan beras merupakan sumber karbohidrat yang paling sering dikonsumsi ibu hamil di Kota Manado. Hal yang sama juga dibahas oleh Widy $^{29}$ dimana semua ibu hamil $(100 \%)$ mengonsumsi beras sebagai sumber karbohidrat.

Berdasarkan zat gizi protein, bahan makanan dengan frekuensi tertinggi yang sering dikonsumsi merupakan ikan air laut. Hal ini masih sejalan dengan penelitian Narasiang et al. ${ }^{28}$ yang menyatakan bahwa ikan air laut merupakan sumber protein yang sering dikonsumsi ibu hamil. Hal ini dikarenakan lokasi penelitian yang mirip yaitu berlokasi di pesisir pantai sehingga sangat mudah menemukan ikan air laut. Hal ini berbeda dengan penelitian oleh Widy $^{29}$ yang menunjukkan ayam merupakan sumber protein yang paling sering dikonsumsi ibu hamil di Kecamatan Bobotsari.

Minyak kelapa merupakan bahan makanan sumber lemak paling sering dikonsumsi oleh ibu hamil di Lolak, yaitu berjumlah 19 responden $(37,25 \%)$ dengan rerata mencapai 149,26gr/hari. Sumber lemak selainn berfungsi sebagai sumber energ bisa menjadi cadangan energi selama dan setelah melahirkan. Menurut Angka Kecukupan Gizi, konsusmsi lemak untuk ibu hamil berkisar $85 \mathrm{~g} / \mathrm{hari}^{30}{ }^{30}$ Hasil penelitian ini juga selaras dengan penelitian Narasiang et al. ${ }^{28}$ yang melaporkan bahwa minyak kelapa merupakan sumber lemak yang paling sering dikonsumsi di Kota Manado dengan konsumsi rerata 118,63gr/ hari.

Berdasarkan frekuesi jarang dan tidak pernah, diperoleh hasil jenis-jenis bahan makanan yang terdiri dari kelapa muda merupakan salah satunya bahan yang jarang dikonsumsi dan sebanyak 50 responden $(98,04 \%)$ tidak pernah mengonsumsi kelapa tua, emping melinjo, corned beef, daging kambing, dan telur bebek asin. Semua bahan makanan tersebut termasuk dalam kelompok protein nabati dan hewani yang baik untuk ibu hamil.

Berdasarkan Angka Kecukupan Gizi (2013), asupan ideal karbohidrat pada ibu hamil sebesar 334-349gr/hari, protein sebesar 76-79gr perhari, dan lemak sebesar $81,85 \mathrm{gr} /$ hari. Dapat dilihat bahwa konsumsi karbohidrat ibu hamil di Lolak sudah sesuai dengan asupan ideal AKG, sedangkan protein sudah melebihi asupan ideal, dan konsumsi lemak, memiliki angka yang cukup tinggi dibandingkan dengan standar $\mathrm{AKG}^{30}$

Dalam penelitian ini juga dinilai hubungan pola konsumsi dan kadar hemoglobin berdasarkan konsumsi protein perhari. Sumber protein dibagi menjadi dua yaitu heme yang biasanya didapatkan dari daging, sedangkan sumber zat besi nonheme bisa didapatkan dari sumber makanan nabati seperti sayuran. Sumber besi berasal dari heme akan langsung mengalami endositosis dan masuk ke dalam lisosom yang selanjutnya dimetabolisme oleh heme oksigenase menjadi bilirubin dan $\mathrm{Fe}^{2+}$, namun mekanisme transpor $\mathrm{Fe}^{2+}$ dari dalam lisosom ke sitosol masih belum diketahui. Absorpsi besi dari sumber non-heme memerlukan proses metabolisme tersendiri karena sumber besi non-heme kebanyakan tersedia dalam bentuk teroksidasi $\left(\mathrm{Fe}^{3+}\right)$ sehingga harus direduksi menjadi bentuk $\mathrm{Fe}^{2+}$ menggunakan enzim ferrireduktase dengan koenzim vitamin $\mathrm{C}$ sebelum ditranspor melewati epitel usus. ${ }^{31}$

Konsumsi protein ibu hamil di Lolak mencapai 236gr/hari dan jika dibandingkan dengan AKG sudah melebihi asupan ideal namun pada hasil penelitian masih ditemukan 48 responden $(94,1 \%)$ dengan kadar hemoglobin $<11 \mathrm{~g} / \mathrm{dl}$.

Berdasarkan hasil penelitian, konsumsi protein ibu hamil di Lolak lebih dominan 
pada protein sumber nabati (non-heme) yang berasal dari kelompok kacangkacangan dan biji-bijian serta olahannya yang rerata konsumsinya mencapai 607,64 gr/hari dibandingkan dengan protein sumber hewani seperti kelompok daging hanya sebesar $41,37 \mathrm{gr} /$ hari. Protein hewani umumnya mempunyai susunan asam amino yang paling sesuai untuk kebutuhan manusia akan tetapi harganya relatif lebih mahal serta pola konsumsi ibu hamil terhadap protein heme sangat rendah terhadap kuantitas serta frekuensi konsumsi. Dari hasil penelitian juga didapatkan 52,9\% responden dengan pendaptan <UMP; hal ini juga menjadi faktor yang berhubungan dengan daya beli yang menurun. ${ }^{20}$

Dalam penelitian ini tidak dilakukan pengambilan data terhadap sumplemen besi serta faktor lain yang berhubungan dengan kadar hemoglobin ibu hamil seperti penyakit infeksi dan pola konsumsi bahan penghambat absorbsi zat besi sehingga tidak diketahui pemgaruh faktor yang berhubungan tersebut.

\section{SIMPULAN}

Dari hasil penelitian ini dapat disimpulkan bahwa sebagian besar ibu hamil memiliki kadar hemoglobin $<11 \mathrm{~g} / \mathrm{dl}$. Tidak terdapat hubungan antara kadar hemoglobin dengan usia ibu, usia kehamilan, jarak kehamilan, riwayat paritas, LILA, status pekerjaan, tingkat pendidikan, dan pendapatan keluarga ibu hamil.

Tidak terdapat hubungan secara statistik antara pola konsumsi dan kadar hemoglobin. Pada pola konsumsi ibu hamil, beras merupakan sumber karbohidrat tertinggi, ikan laut sumber protein tertinggi, dan minyak kelapa sumber lemak tertinggi.

\section{SARAN}

Perlu dilakukan penelitian lebih lanjut mengenai faktor yang berhubungan dengan kadar hemoglobin di Puskesmas Lolak. Disarankan kepada petugas kesehatan untuk melakukan edukasi pentingnya gizi terhadap masyarakat, khususnya ibu hamil.

\section{DAFTAR PUSTAKA}

1. Kemenkes RI. Penuhi Kebutuhan Gizi pada 1000 hari pertama kehidupan 2012. Jakarta. [cited 2017 Dec 30]. Available from: http://www.depkes.go.id/pdf. php?id=2014

2. Menko K. Pedoman perencanaan program gerakan nasional percepatan perbaikan gizi dalam rangak seribu hari pertama kehidupan 2013. Republik Indonesia [cited 2017 Dec 30]. Available from: https://www.bappenas.go.id/files/5013/ 8848/0466/PEDOMAN_SUN_10_Sept 2013.pdf

3. Ruel MT, Alderman $\mathbf{H}$, the maternal and child nutrition study group. Nutrition sensitive interventions and programmes: how can they help to accelerate progress in improving maternal and child nutrition? Lancet 2013;383:536-51.

4. Bekele A, Tilahun M, Mekuria A. Prevalence of Anemia and its associated factors among pregnant women attending antenatal care in Health Institutions of Arba Minch Town, Gamo Gofa Zone, Ethiopia: a cross-sectional study. Anemia. 2016;1:9.

5. WHO. The Global Prevalence of Anemia in 2011. 2015

6. WHO. WHO Global Targets 2025: Anemia Policy Brief. [cited 2017 Dec 30]. Available from: http://www.who.int/ nutrition/publications/globaltargets 2025 _policybrief_anaemia/en/

7. Kemenkes. Riset Kesehatan Dasar 2013.

8. Taner CE, Ekin A, Solmaz U,Gezer C, Çetin B, Keleşoğlu M, et al: Prevalence and risk factors of anemia among pregnant women attending a high-volume tertiary care center for delivery. J Turk Ger Gynecol Assoc 2015;16:231-6.

9. Sunyoto D, Ari S. Buku Ajar: Statistik Kesehatan Parametrik, Non Parametrik, Validitas, dan Reliabilitas. Yogyakarta: Nuha Medika, 2013.

10. Sudikno, Sandjaja. Prevalensi dan faktor resiko anemia pada wanita usia subur di rumah tangga miskin di Kabupaten Tasikmalaya dan Ciamis, Provinsi Jawa Barat. Jurnal Kesehatan Reproduksi. 2016;7(2):71-82.

11. Muhilal, Sahidin S. Ketelitian hasil penentuan hemoglobin dengan cara 
sianmethemoglobin, cara Sahli dan sianmethemoglobin-tidak langsung. Jurnal Penelitian Gizi \& Makanan. 1980;4:15-20.

12. Purwaningtyas ML, Galuh NP. Faktor kejadian anemia pada ibu hamil. HIGEIA. 2017;1(3):43-54.

13. Berekal S, Gudeta AN, Reta MA, Ayana LA. Prevalence and associated risk factors of anemia among pregnant women in rural part of JigJiga City, Eastern Ethiopia: a cross sectional study. J Preg Child Health. 2017;4(3).

14. Kefiyelew F, Zemene E, Asres Y, Gedefaw L. Anemia among pregnant woman in Southeast Ethiopia: prevalence, severity and associated risk factors. Biomed Central (BMC). 2014;7(1):771.

15. Supariasa IDN, Bakri B, Fajar I. Penilaian Status Gizi. Jakarta: EGC, 2002.

16. Bedi R, Acharya R, Gupta R, Pawar S, Sharma R. Maternal factors of anemia in 3rd trimester of pregnancy and its association with fetal outcome. International Multispeciality Journal of Health (IMJH). 2015;1;7.

17. Obai, Ondongo, Wanyama. Prevalence of anemia and associated risk factors among preganant women attending antenatal care in gulu and hoima regional hospital in Uganda. BioMed Central Pregnancy and ChildBirth. 2016;16:76

18. Manuaba IBG. Ilmu Kebidanan, Penyakit Kandungan dan Keluarga Berencana. Jakarta: EGC, 2002.

19. Handayani SK. Faktor-faktor yang Berhubungan dengan kejadian anemia pada ibu hamil trimester III di wilayah Puskesmas Liang Anggang Kota Banjarbaru Kalimantan Selatan Tahun 2012 [Skripsi]. Depok: Fakultas Kesehatan Masyarakat Program Studi Kesehatan Masyarakat Universitas Indonesia; 2012.

20. Prahesti R. Analisis faktor-faktor yang berhubungan dengan kejadian anemia pada ibu hamil di Puskesmas Prambanan, Sleman, Yogyakarta
[Tesis]. Surakarta: Pasacasarjana Universitas Sebelas Maret; 2017.

21. Tjitaningrum AAA. Diagnosis dan tatalaksana anemia defisiensi besi. Majority. 2016;5(5):169.

22. Aisyah RD, Fitriyani. Hubungan frekuensi ANC, dukungan suami, pekerjaan dengan kejadian anemia pada ibu hamil. The 4th University Research Colloquium (URECOL), 2016

23. Ngurah Rai IGB. Analisis faktor-faktor yang berhubungan dengan kadar hemoglobin pada ibu hamil. e-Bm. 2016;4;2.

24. Ernawatik. Faktor-faktor yang mempengaruhi kejadian anemia di Puskesmas Karanganyar [Skripsi]. Yogyakarta: Program Studi Bidan Pendidik Jenjang Diploma IV Fakultas Ilmu Kesehatan Universitas 'Aisyiyah; 2017.

25. Lokare PO, Karanjekar VD, Gattani PL, Kulkarni AP. A study of pevalence of anemia and sociodemographic factors associated with anemia among pregnant woman in Aurangabad City, India. Ann Nigerian Med. 2012;6:30-4.

26. Notoatmojo S. Promosi Kesehatan dan Ilmu Perillaku. Jakarta: Rineka Cipta, 2007.

27. Kemenkes RI Direktorat Jendral Bina Gizi dan Kesehatan Ibu dan Anak. Pedoman Gizi Seimbang 2014.

28. Narasiang BR, Mayulu N, Kawengian S. Gambaran pola konsumsi makanan pada ibu hamil di Kota Manado. eBm. 2016;4(2).

29. Widy US. Analisa pola makan ibu hamil dengan kondisi kurang energi kronik (KEK) di Kecamatan Bobotsari, Kabupaten Purbalingga [Skripsi]. Yogyakarta: Universitas Negeri Yogyakarta; 2014.

30. MenKes RI. Peraturan Menteri Kesehatan Republik Indonesia nomor 75 tahun 2013 tentang angka kecukupan gizi yang dianjurkan bagi bangsa Indonesia. 2013.

31. Perdana WY, Jacobus DJ. Hepcidin dan anemia defisiensi besi. CDK-235. 2015;42(12):919-26. 